\title{
THE DISTRIBUTION OF BENTHIC FORAMINIFERA IN DAMAR AND JUKUNG ISLAND, SERIBU ISLANDS
}

\author{
Suhartati M. Natsir \\ Oceanography-LIPI \\ Jln. Pasir Putih 1, Ancol Timur, Jakarta, Indonesia (14430) \\ E-mail: suhartatinatsir@yahoo.com \\ Received: 9 March 2010 Accepted: 1 September 2010
}

\begin{abstract}
Seribu Islands are archipelago within Jakarta Bay built upon the pleistocene coral formation of the Sunda Shelf. The islands are characterized by unique and high biodiversity such as coral reefs. Since coral reef degradation would lead to a decrease of human prosperity, the determination of the coral reef quality is of high importance. Foraminifera offers an early warning system for the coral reef condition, as exemplified by the FORAM Index, i.e. Foraminifera in Reef Assessment and Monitoring Index. This study compared the foraminiferal community structure and the FORAM Index of two islands between Damar Besar and Jukung. Both islands were dominated by symbiont-bearing foraminifera of the genera Amphistegina, Calcarina, Heterostegina, Marginophora, and Operculina. However, the number of benthic foraminifera at Jukung Island was higher than that at Damar Besar Island, having 17 individuals per species on average. Jukung Island was a conducive site to reef growth, as indicated by FORAM Index (between 6,48 and 6,57), and Damar Besar Island was liable to environmental change.
\end{abstract}

Keywords: Foraminifera, FORAM Index, Jukung and Damar Besar Islands, coral reef Seribu Islands.

\section{INTRODUCTION}

Seribu Islands belong to the Northern Java Sea waters of Jakarta Bay. It covers a total of 108.000 hectares and consists of coral that was built up from the Pleistocene onwards. Jakarta Bay is an estuary of several rivers such as Bekasi, Citarum, Ciliwung, Cisadane, and Angke Rivers. The rivers bring waste water from Jakarta and surrounding, which now is a densely populated settlement with agricultural activities and rapidly increasing industrial activities. The bay also receives disposal of its voyage traffic. As a result, many pollutants, being solid, liquid, organic, heat, detergents, pesticides, heavy metals or mud, finally end up in Jakarta Bay (Nontji and Supangat, 1977). Jukung Island is one of the islands of northern group with better environmental condition than that of the southern group, such as Damar Besar Island (Soekarno, 1989 in Giyanto and Soekarno, 1997).

Coral reef ecosystems have a significant importance for many marine organisms and hence its conservation is a necessity. To check for eventual coral reef degradation, several monitoring strategies have been performed, one of which making use of the foraminiferal community structure: FORAM Index, i.e. Foraminifera in Reef Assessment and Monitoring Index (Hallock et al., 2003). The FORAM Index can be used to address local impacts and to assist in differentiating between the local impacts as a result of a poor water quality and those as a result of regional to global change issues (Hallock et al., 2003).

The Phylum Foraminifera consists of animals generally living in the marine environment. They are sensitive to environmental change, have various distributions, and live only in certain sites. Shells of dead foraminifera sink down to the sea bottom and may accumulate in particular areas, then becoming a key characteristic for rock age and the geological past. Also, micropaleontology is generally based on foraminifer microfossils (Buzas and Gupta, 1982) besides nannoplankton, 
radiolaria, ostrcodes etc. Foraminifera naturally live abundantly in sediments, with depth being an important structuring factor (Boltovskoy and Wright, 1976). Foraminifera also associate with coral reefs. Yamano et al. (2000) found that foraminifera were covering $30 \%$ of the sediment of Green Island, Great Barrier Reef, Australia, and hence were an important contributor to the coral reefs build up. The dominant were Amphistegina, Baculogypsina, and Calcarina.

The aim of this study is to determine the benthic foraminiferal distribution at Jukung and Damar Besar Island,Seribu Island complex and to classified the environmental quality of their coral reefs based on FORAM Index.

\section{MATERIAL AND METHODS}

\section{Sampling and Laboratory Analysis}

Foraminiferal fauna at four sides of the Jukung and Damar Besar Island were sampled (Figure 1). At each sampling station, five samples were collected on 27-30 January 2008. The samples were collected using a Van Veen grab, placed in plastic bags, and preserved in 10\% formaldehyde- water solution for 24 hours. A $100 \mathrm{~g}$ of sediment subsample was then put into a labeled plastic bag and preserved again in a 10\% formaldehyde-water solution for 24 hours. The samples were then rinsed with water on a filter tray (mesh size of sieve $0,063 \mathrm{~mm} ; 0,250 \mathrm{~mm} ; 0,5 \mathrm{~mm} ; 0,1 \mathrm{~mm}$ and $0,2 \mathrm{~mm}$ ) and dried in the oven at temperature $30^{\circ} \mathrm{C}$. The dry samples were placed into a labeled plastic bag for further analysis. Specimens were described under a microscope with magnification $10 \times 100$ based on their morphology such as shell, chamber shape, formation and number ornaments, aperture slope and aperture position, and additional chamber. Species identification mainly refered to Graham and Militante (1959), Barker (1960), Cushman (1969), Albani (1979), and Loeblich and Tappan (1992).

\section{The FORAM Index}

FORAM Index (FI) was calculated based on the formula of Hallock et al. (2003):

$\mathrm{FI}=(10 \times \mathrm{Ps})+(\mathrm{Po})+(2 \times \mathrm{Ph})$

In which,

FI $=$ FORAM Index

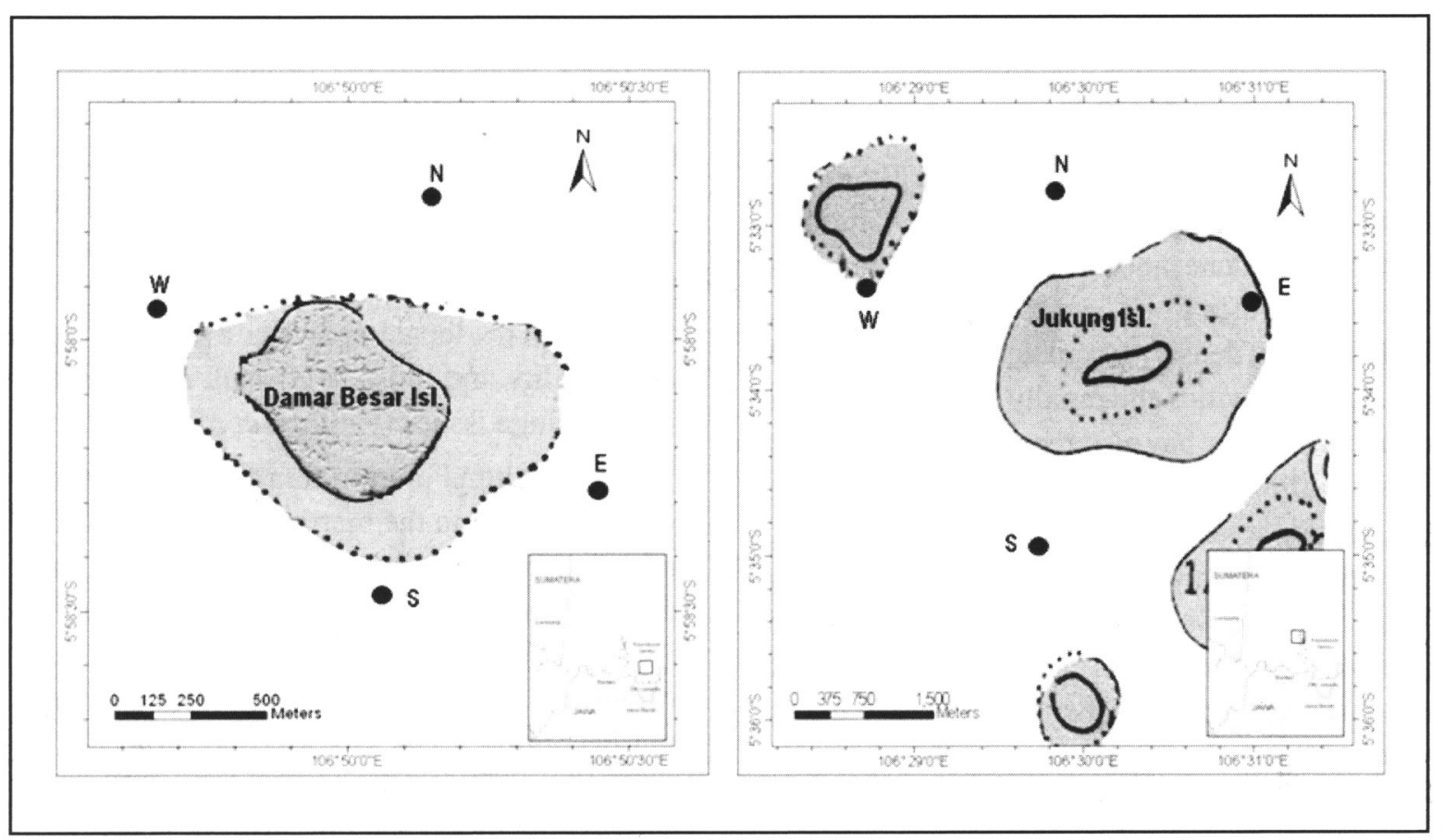

Figure 1. Sampling sites of Damar Besar and Jukung Islands of Thousand Islands. Remark; N: North, E: East, S: South, and W: West. 
Ps $=$ Ns/ T, with "Ns" the number of symbiontbearing foraminifera, such as Amphistegina, Heterostegina, Alveolinella, Borelis, Sorites, Amphisorus, Marginophora.

$\mathrm{Po}=\mathrm{No} / \mathrm{T}$, with "No" the number of opportunistic foraminifera, such as Ammonia, Elphidium, everal genera from family Trochaminidae, Lituolidae, Bolivinidae, and Buliminidae.

$\mathrm{Ph}=\mathrm{Nh} / \mathrm{T}$, with "Nh" the number of other small heterotrophic foraminifera, such as many genera of Miliolida, Rotaliida, Textulariida.

$\mathrm{T}=$ Number of specimens counted

The FORAM Index can be interpreted as:

$\mathrm{FI}>4=$ environment conducive to reef growth
$3<\mathrm{FI}<5=$ environmental change

$2<\mathrm{FI}<4=$ environment marginal for reef growth and unsuitable for recovery

$\mathrm{FI}<2=$ stressed conditions unsuitable for reef growth

\section{RESULTS}

In total, 31 species of 20 genera and 12,705 individuals of benthic foraminifera were collected Jukung Island hosted most of the foraminifera (1,1073 specimens). The foraminifera were classified as symbiont-bearing, opportunistic, and other small heterotrophic foraminifera (Table 1) with composition as in Figure 2 and 3, and abundances as in Figure 4 and 5. The symbiontbearing foraminifera comprised $48.28 \%$ of total

Table 1. Collected species of Damar Besar and Jukung Island, classified by the three functional group (Hallock, 2003)

\begin{tabular}{|c|c|}
\hline Functional groups & Species \\
\hline \multirow{13}{*}{ Symbiont-bearing } & Amphistegina gibbosa \\
\hline & Amphistegina lessonii \\
\hline & Amphistegina quoyii \\
\hline & Amphistegina radiata \\
\hline & Calcarina calcar \\
\hline & Calcarina spengleri \\
\hline & Calcarina hispida \\
\hline & Heterostegina depressa \\
\hline & Marginophora vertebralis \\
\hline & Operculina ammonoides \\
\hline & Operculina gaimardii \\
\hline & Operculina tuberculata \\
\hline & Operculina complanata \\
\hline \multirow{9}{*}{ Opportunistic } & Ammonia beccarii \\
\hline & Elphidium advenum \\
\hline & Elphidium craticulatum \\
\hline & Elphidium crispum \\
\hline & Pseudorotalia schroeteriana \\
\hline & Quinqueloculina parkery \\
\hline & Quinqueloculina cultrata \\
\hline & Textularia agglutinans \\
\hline & Spiroloculina communis \\
\hline \multirow{9}{*}{ Other small heterotrophic } & Triloculina tricarinata \\
\hline & Acervulina inherens \\
\hline & Adelosina semitriata \\
\hline & Ammomassilina alveoliniformis \\
\hline & Chrysadinella dimorpha \\
\hline & Cymbaloporetta squammosa \\
\hline & Flintina bradiana \\
\hline & Gaudryina rugulosa \\
\hline & Rosalina globularis \\
\hline
\end{tabular}




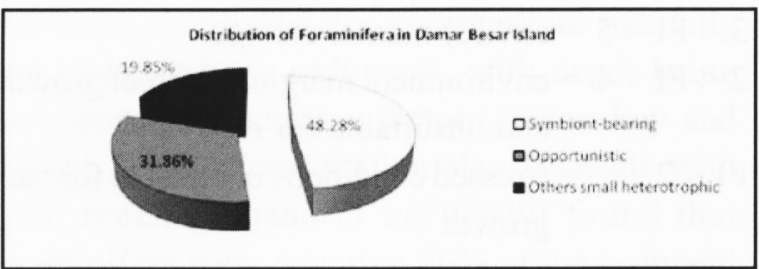

Figure 2. Distribution of symbiont-bearing, opportunistic, and other small heterotrophic foraminifera at Damar Besar Island

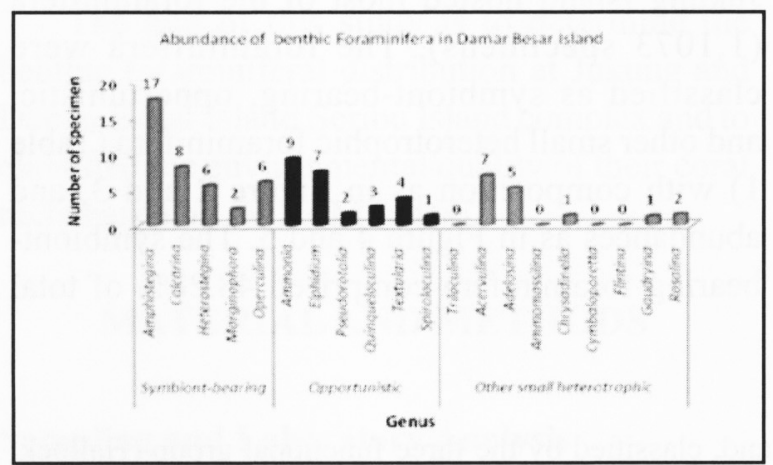

Figure 4. The abundance of benthic foraminifera in Damar Besar Island

number of benthic foraminifera in Damar Besar Island. Opportunistic and other small heterotrophic foraminifera respectively reached $31.86 \%$ and $19.85 \%$ of the abundance. Jukung Island consisted of $60.73 \%$ of symbiont-bearing foraminifera, $28.73 \%$ of opportunistic foraminifera, and $10.54 \%$ of other small heterotrophic foraminifera (Figure 3).

Based on the FORAM index, environmental condition of Damar Besar and Jukung Island was relatively conducive to reef growth, but that of Damar Besar Island was liable to environmental change with FORAM index 5.28 to 5.72 (Table 2). This result was supported by environmental conditions (abiotic factors) of the particular sites. Especially for transparency, Jukung Island was recognized at 9 to $11 \mathrm{~m}$, better than Damar Besar Island that was recognize at $4 \mathrm{~m}$ on every sampling sites. The environmental condition of each islands was given in Tabel 2 .

\section{DISCUSSION}

FORAM Index was applied by Schuetch and Frank (2008) to assess whether changes since 1928 in the coral population of Low Isles Reef, located in

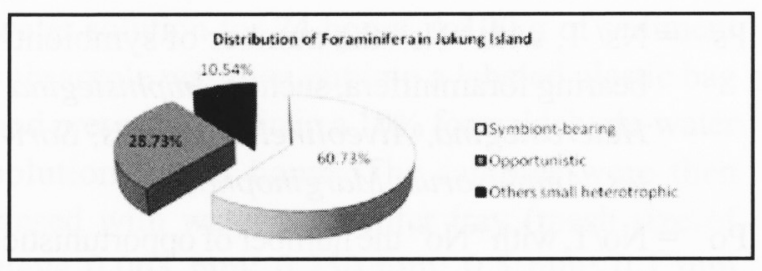

Figure 3. Distribution of symbiont-bearing, opportunistic, and other small heterotrophic foraminifera at Jukung Island

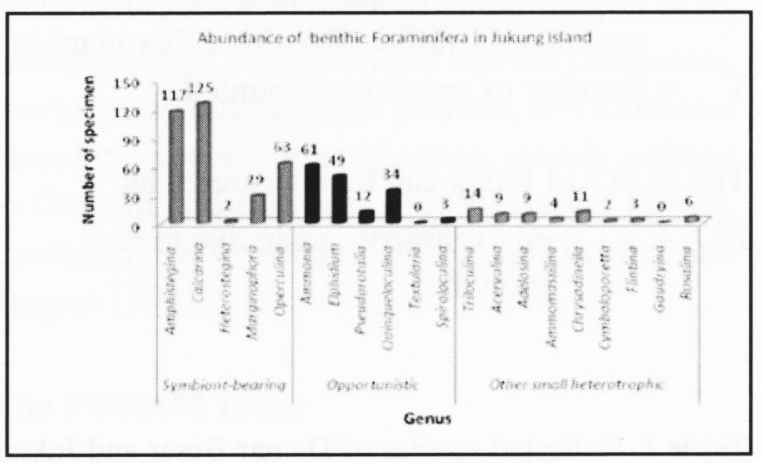

Figure 5. The abundance of benthic foraminifera in Jukung Island

the wet tropics of the Great Barrier Reef Province, Australia, were related to land use activities that have increased the fluxes of sediment and nutrients to coastal areas. The lower FORAM Index values are concentrated in the anchorage and areas of the reef flat that lie directly west of the mangrove swamp. This distribution which is consistent with previous observations that scleractinian corals in these areas were unable to recover from damage inflicted by a 1950 cyclone.

The FORAM index at Jukung Island was found to range between 6.48 and 6.57 showed that the environmental condition were conducive to reefs growth, but environmental condition of Damar Besar Island was tending to environmental change with FORAM index 5.28 to 5.72. Hallock et al. (2003) declared that FORAM index more than 4 was conducive to reefs growth and 3 to 5 indicates the transition of environment marginal for reef growth and unsuitable for recovery to conducive.

The dominant benthic foraminifera on every sampling sites were Amphistegina, especially Amphistegina lessonii (d'Orbigny) and A. gibbosa (d'Orbigny). These spesies were encountered 
abundantly at every sampling sites. Renema (2008) also encountered two species of Amphistegina associated with the reef slope of coral rubble or coral fragments within the sandy substrate at Seribu Islands, together with many species of Calcarina. Calcarina was abundant on the reef flat and reef crest, or associated with algae and macroalgae, such as Sargassum, Galaxaura, and Chelidiopsis Renema (2008). Barker (1960) encountered these genera in Admiralty Island, Pacific at a depth of 16 to $25 \mathrm{~m}$, whereas, Graham and Militante (1959) encountered them in Puerto Galera Bay, Philipines, at 8.5 to $14.5 \mathrm{~m}$.

The number of specimens found at Jukung Island was much higher than that of Damar Besar Island. Most species collected at Damar Besar, were respresented by 10 specimens on average, except for Amphistegina. At Jukung Island, most species were represented by more than 50 individuals, especially the symbiont-bearing foraminifera such as Amphistegina and Calcarina.

Jukung Island belongs to northern group of Seribu Islands having a depth of $22.5-27.5 \mathrm{~m}$. This showed the condition was beneficial for growth and reproduction of many benthic foraminifera such as Amphistegina lessonii of suborder Rotaliina. Hallock in Buzas and Gupta (1982) deciared that Amphistegina lobifera prosperously lives, grows, and reproduces in shallow water (less than $3 \mathrm{~m}$ ) with a high intensity of sunlight, whereas Amphistegina lessonii would thrive in deeper waters.
Generally, water condition of northern Seribu Islands is better than that of the southern side. This could be explaned from water transparancy. Transparancy in 9-11 m depth at Jukung (nothern) higher than that in $4 \mathrm{~m}$ depth of Damar (Southern).

The lower abundance of benthic foraminifera on Damar Besar could be linked to the dominance of muddy and fine grained sediments, negatively impacting the water transparency. Several opportunistic species of foraminifera, such as Ammonia beccarii and Elphidium craticulatum, were collected abundantly at every sampling site both at Damar Besar and Jukung Island. Their abundance however differed significantly between both Islands. Hence, southern Seribu Islands were still affected by land based pollution and sedimentation from the mainland of Jakarta. The bay should hence be considered in suboptimal environmental conditions for coral reef development, as indicated by the benthic foraminifera. Sunlight penetration would be impeded by suspended material, and then reduced the oxygen content of the waters. Lack of oxygen content affected the decrease of benthic foraminifera (Boltovskoy and Wright, 1976).

\section{CONCLUSION}

Jukung and Damar Besar Island were both dominated by symbiont-bearing foraminifera. On average, the number of benthic foraminifera at Jukung Island was higher (max. 125 individuals) than that at Damar Besar, with a maximum of 17

Table 2. FORAM Index on four sampling sites of Damar Besar and Jukung Island

\begin{tabular}{|c|c|c|c|c|c|}
\hline \multirow{3}{*}{ Island } & & \multicolumn{4}{|c|}{ Sampling sites } \\
\cline { 2 - 6 } & & North & East & South & West \\
\hline \multirow{3}{*}{ Damar Besar } & Ps & 45.37 & 48.17 & 49.38 & 50.24 \\
\cline { 2 - 6 } & Po & 35.37 & 31.30 & 30.67 & 30.10 \\
\cline { 2 - 7 } & Ph & 19.27 & 20.54 & 19.95 & 19.66 \\
\cline { 2 - 7 } & FORAM Index & 5.28 & $\mathbf{5 . 5 4}$ & $\mathbf{5 . 6 4}$ & $\mathbf{5 . 7 2}$ \\
\hline \multirow{3}{*}{ Jukung } & Ps & 32.67 & 30.87 & 31.40 & 30.88 \\
\cline { 2 - 7 } & Po & 7.21 & 8.29 & 7.52 & 8.86 \\
\cline { 2 - 6 } & Ph & 6.48 & 6.56 & 6.57 & 6.57 \\
\hline
\end{tabular}

Ps : portion of symbiont-bearing foraminifera

Po : portion of opportunistic foraminifera

$\mathrm{Ph}$ : portion of other small heterotrophic foraminifera 
Table 3. Environmental conditions (abiotic factors) on Damar Besar and Jukung Island

\begin{tabular}{|c|c|c|c|c|}
\hline \multirow{2}{*}{\multicolumn{2}{|c|}{ Paramater }} & \multirow{2}{*}{ Unit } & \multicolumn{2}{|c|}{ Island } \\
\hline & & & Damar Besar & Jukung \\
\hline \multicolumn{2}{|c|}{ Depth } & $\mathrm{m}$ & $11-37$ & $22,5-27,5$ \\
\hline \multirow{2}{*}{ Temperature } & Surface & \multirow{2}{*}{${ }^{\circ} \mathrm{C}$} & $30,00-30,18$ & $29,12-29,39$ \\
\hline & Bottom & & $30,00-30,12$ & $29,10-29,39$ \\
\hline \multirow{2}{*}{ Salinity } & Surface & \multirow{2}{*}{ psu } & $32,10-32,44$ & $32,15-32,54$ \\
\hline & Bottom & & $32,12-32,40$ & $31,26-32,52$ \\
\hline \multicolumn{2}{|c|}{$\mathrm{pH}$} & - & $7,55-7,90$ & $7,75-7,90$ \\
\hline \multicolumn{2}{|c|}{ Transparency } & $m$ & 4,00 & $9,00-11,00$ \\
\hline
\end{tabular}

specimens per species. Based on the FORAM index, Jukung Island was a site conducive to reef growth, as indicated by FORAM index between 6.48 and 6.57. Whereas, Damar Besar Island showed FORAM Index of 5.28 to 5.72 , which means tending to environmental change. The symbiont-bearing foraminifera of the two islands were the genera Amphistegina, Calcarina, Heterostegina, Marginophora, and Operculina.

\section{REFERENCES}

Albani, R. D. 1979. Recent Shallow Water Foraminifera From New South Wales. AMS Handbook No. 3. The Australian Marine Assosiation, Australia.

Barker, R.W. 1960. Taxonomic Notes. Society of Economic Paleontologist and Mineralogist. Special Publication No. 9. Tulsa. Oklahoma. USA.

Boltovskoy, E. and R. Wright. 1976. Recent Foraminifera. Dr. W. June. B. V. Publisher. The Haque. Netherland.

Buzas. M.A. and B.K. Gupta. 1982. Foraminifera: Notes for a Short Course. University of Tennessee. Department of Geological Science. Louisiana.

Cushman, J. A. 1969. Foraminifera-Their Classification and Economic Use. Harvard University Press, Cambridge, Massachusetts.

Giyanto dan Soekarno. 1997. Perbandingan Komunitas Terumbu Karang pada Dua Kedalaman dan Empat Zona yang Berbeda di Pulau-Pulau Seribu, Jakarta. Oseanologi dan Limnologi di Indonesia. 30: 33-51.
Graham, J.J. and P.J. Militante. 1959. Recent Foraminifera from the Puerto Galera Area Northern Mindoro, Philippines. Stanford University. California.

Hallock, P., B.H. Lidz. E.M. Cockey-Burkhard, and K.B. Donnelly. 2003. Foraminifera as Bioindicators in Coral Reef Assessment and Monitoring: the FORAM Index. Environmental Monitoring and Assessment. 81(1-3): 221-238.

Loeblich, A. R. and Tappan, H. 1992. Present Status of Foraminiferal Classification, in Studies in Benthic Foraminifera, (eds Y. Takayanagi and T. Saito), Poceedings of The Forth International Symposium on Benthic Foraminifera, Sendai, 1990 (Benthos '90), Tokai University Press, Tokyo, Japan, pp. 93-102.

Nontji, A. and Supangat, I. 1977. Pelagic Environment in the Western Part of Jakarta Bay. Marine Research in Indonesia 20: 69-85.

Renema, W. 2008. Habitat Selective Factors Influencing the Distribution of Larger Benthic Foraminiferal Assemblages Over the Kepulauan Seribu. Marine Micropaleontology 68 (2008) 286-298.

Schueth, J.D. and T.D. Frank. 2008. Reef Foraminifera as Bioindicators of Coral Reef Health: Low Isles Reef, Northern Great Barrier Reef, Australia. Journal of Foraminiferal Research, 38(1):11-22.

Yamano, H., T. Miyajima, and I. Koike. 2000. Importance of Foraminifera for the Formation and Maintenance of A Coral Sand Clay: Green Island, Australia. Coral Reefs (19): 51-58. 